\title{
The effects of Brazilian tea (Stachytarpheta jamaicensis) and Bitter kola (Garcinia kola) seed meal on the growth and gonad development of the African catfish Clarias gariepinus (Burchell, 1822)
}

\author{
Sunday Ben Ekanem ${ }^{1}$ • Victor Oscar Eyo 2* (D) Esther Emmanuel Okon ${ }^{1}$ \\ 1Department of Zoology and Environmental Biology, University of Calabar, P.M.B. 1115 Calabar, Cross River State, Nigeria \\ 2Institute of Oceanography, University of Calabar, P.M.B. 1115 Calabar, Cross River State, Nigeria \\ Corresponding author: sirvick2003 @yahoo.com
}

Received date: 10.06 .2016

Accepted date: 07.03.2017

How to cite this paper:

Ekanem, S.B., Eyo, V.O. \& Okon, E.E. (2017). The effects of Brazilian tea (Stachytarpheta jamaicensis) and Bitter kola (Garcinia kola) seed meal on the growth and gonad development of the African catfish Clarias gariepinus (Burchell, 1822). Ege Journal of Fisheries and Aquatic Sciences, 34(2): $179-185$.

doi:10.12714/egejfas.2017.34.2.09

\begin{abstract}
A 90-day study was undertaken to evaluate the effects of Stachytarpheta jamaicensis and Garcinia kola seed meal on the growth and gonad development of the African catfish, Clarias gariepinus. Ninety (90) fingerlings were stocked in nine rectangular concrete tanks (10 each) labeled $A_{1}, A_{2}, A_{3}, B_{1}, B_{2}, B_{3}, C_{1}, C_{2}$ and $\mathrm{C}_{3}$ with a total water volume of $887.04 \mathrm{~m}^{3}$. Three isonitrogenous diets $(\mathrm{A}, \mathrm{B}$, and $\mathrm{C}$ ) with $40 \%$ crude protein including the control diet containing $0 \mathrm{~g}$ of $\mathrm{S}$. jamaicensis and $\mathrm{Og}$ of $\mathrm{G}$. kola meal, 70 of $S$. jamaicensis leaf meal and $35 \mathrm{~g}$ of $\mathrm{G}$. kola meal $+35 \mathrm{~g}$ of $S$. jamaicensis leaf meal in the feed were fed to the fish at $5 \%$ body weight. Fish in A-series tanks were fed diet A, fish in B-series tanks were fed diet B while fish in C-series tanks were fed diet C. Weight gain, length gain, SGR, GR, and FCR were better in fish fed the diet $A$ but not significantly different $(P>0.05)$ from fish fed diet $B$ and diet $C$. Female GSI, male and female gonad weight were better in fish fed diet $A$ but not significantly different $(P>0.05)$ from fish fed diet $B$ and diet $C$. However, male GSI $(1.39 \pm 0.01)$ of fish fed the diet $A$ was significantly different $(P<0.05)$ from male fish fed diet $B(0.94 \pm 0.15)$ and diet $C(0.95 \pm 0.05)$. Fecundity of fish fed diet $A(11,834 \pm 1644$ eggs $)$ was significantly different $(P<0.05)$ from fish fed diet $B(6375 \pm 995 \mathrm{eggs})$ and diet $C(10,236 \pm 896 \mathrm{eggs})$. Histology of ovaries and testes of fish fed the three experimental diets showed normal distribution of oocytes and testicular cells. Our findings imply that the combination of $G$. kola seed meal and $S$. jamaicensis leaf meal in feed negatively affects the growth, fecundity, and gonad development of $C$. gariepinus which can be detrimental to aquaculture production.
\end{abstract}

Keywords: Stachytarpheta jamaicensis, Garcinia kola, growth, gonad development, fecundity, Clarias gariepinus

\section{INTRODUCTION}

In Nigeria, the popularity of the African Catfish Clarias gariepinus (Burchell, 1822) continues to increase among fish consumers due to its excellent meat quality and taste especially in different processed forms such as smoked, fried, and dried form. Also, its affordability and richness in nutrients required for good health and growth such as omega-3- fatty acid, phosphorus, thiamine, riboflavin, vitamins $A$ and $D$, calcium, and iron increases its consumption rate in Nigeria (Eyo and Ekanem, 2011; Eyo et al. 2013). Among fish species cultured in Nigeria, C. gariepinus remains the most cultivated species which is ascribed to several favorable characteristics exhibited by this species. Such favorable characteristics reported by Eyo et al. (2014) include; fast growth rate, ability to strive under varying range of environmental conditions, disease resistance, tolerate high stocking densities in captivity, acceptability of formulated feed, high fecundity, high market value, excellent taste, excellent meat quality, and ease of artificial breeding.

The use of plant extracts and phytochemicals in animal production system to boost growth and gonad development is gradually gaining global popularity. According to Dada and Ikuerowo (2009), attention is now shifted from the use of synthetic drugs to natural plant products in aquaculture to enhance growth and reproductive performance. Plants products are reported to pose little or no side effects in both the cultured fish and fish consumer. Also, plants products are biodegradable and do not remain in the fish tissue for a longer time making fish biologically safe to consume. According to Ajayi et al. (2013), many plants have high nutritive values such as proteins, carbohydrates, fibre, lipids, and minerals while others have industrial values such as sources of dyes, starches and vitamins.

The Brazilian tea Stachytarpheta jamaicensis (Vahl, 1804) commonly known as blue porterweed, blue snakeweed, bastard vervain, Jamaica vervain, and light-blue snakeweed is a species of plant that belongs to family Verbenaceae (Wikipedia, 2016). This plant species which is native to the Caribbeans is also pantropical, found in the Southeastern Asia, Indian Subcontinent, and West Tropical Africa (Wikipedia, 2016). Bush tea prepared from its fresh leaves are consumed 
as a cooling tonic and blood cleanser which is effective in asthma and stomach ulcer treatments (Becker, 2004).

Bitter kola seed Garcinia kola (Heckel) popularly known as "Efiari" by the Ibibio and Efik tribes in Southern Nigeria is widely used in traditional medicinal due to its efficacy in treatments of various ailments. According to Iwu et al. (1990), G. kola contains a complex mixture of phenolic compounds including bioflavonoids, benzophenones, and xanthones. The phenolic compounds of $G$. kola possess anti-microbial, antiinflammatory, antiviral properties, and anti-diabetic (Adedeji et al. 2006). Recently, the potential of $G$. kola extract as growth and fertility enhancer has been investigated in different fish species (Dada et al. 2009). Several authors have supplemented fish diets with different levels of G. kola seed powder to improve growth performance, feed utilization, survival, and fertility (Dada and Ikuerowo, 2009; Dada and Ebhodage, 2011; Dada and Oviawe, 2011; Dada and Ogunduyile, 2011)

Although culture of $C$. gariepinus seems to be successful in Nigeria, several farmers are still combating momentous challenges such as poor growth and fertility, which hinders the success of their fish production (Awom and Eyo, 2016). Several plant products are being screened for enhancement of spawning of this species in captivity; G. kola and S. jamaicensis are among those. Therefore, the objective of this study was to determine the effects of $G$. kola seed meal, $S$. jamaicensis leaf meal, and their combination on growth performance and gonad development of the African Catfish (C. gariepinus).

\section{MATERIALS AND METHODS}

\section{Experimental design}

This study was conducted for ninety (90) days using a triplicate setup of nine (9) rectangular concrete tanks ( $A_{1}, A_{2}, A_{3}$, $B_{1}, B_{2}, B_{3}, C_{1}, C_{2}$, and $C_{3}$ ) with a total water volume of 887.04 $\mathrm{m}^{3}$. Three isonitrogenous fish feeds (Diet $\mathrm{A}$, Diet $\mathrm{B}$, and Diet $\mathrm{C}$ ) containing $40 \%$ crude protein were used in feeding the fish. Diet A was the control diet, Diet B contained $70 \mathrm{~g}$ of $\mathrm{S}$. jamaicensis, and Diet $C$ contained $35 \mathrm{~g}$ of $\mathrm{G}$. kola mixed with $35 \mathrm{~g}$ of $S$. jamaicensis, in addition to other feed ingredients as shown in table 1. Ninety (90) fingerlings of $C$. gariepinus with a mean body weight of $16.40 \pm 2.04 \mathrm{~g}$ and total length $13.32 \pm 0.25 \mathrm{~cm}$ were collected from the Institute of Oceanography Hatchery Complex, University of Calabar and used for the study (10 fingerlings in each tank). After stocking, the fishes were acclimated for two weeks in the tanks. During acclimation period, the fish were fed to satiation with Coppens fish feed. Prior to the start of experiment, the experimental fishes were starved for 24 hours before introducing the experimental diets to the different tanks according to label. Fish in tanks $A_{1}, A_{2}$, and $A_{3}$ were fed to diet $A$ (control diet), fish in tanks $B_{1}, B_{2}$, and $B_{3}$ were fed to diet $B$ (containing $70 \mathrm{~g}$ of $S$. jamaicensis) while fish in tanks $C_{1}, C_{2}$ and $C_{3}$ were fed diet $C$ (containing $35 \mathrm{~g}$ of $G$. $k o l a+35 \mathrm{~g}$ of $S$. jamaicensis). The fishes were fed twice daily with $5 \%$ of their body weight. Before the experiment started, the initial length and weight of each fish were taken using measuring board for length and an electronic weighing balance (Metlar 5000D) for weight. The lengths were recorded in $\mathrm{cm}$ while the weights were recorded in grams. Table 1 shows the composition of the three experimental diets in grams per kilogram $(\mathrm{g} / \mathrm{kg})$.

Table 1. Experimental diet composition in grams per kilogram

\begin{tabular}{lccc}
\hline INGREDIENTS & $\begin{array}{c}\text { DIET A } \\
\text { (Control) }\end{array}$ & $\begin{array}{c}\text { DIET B } \\
\text { (70g S. } \\
\text { jamaicensis) }\end{array}$ & $\begin{array}{c}\text { DIET C } \\
\text { (35 g of G. kola + } \\
\text { 35g of S. } \\
\text { jamaicensis) }\end{array}$ \\
\hline Blood meal (BM) & 150 & 200 & 200 \\
$\begin{array}{l}\text { Groundnut meal } \\
\text { (GNM) }\end{array}$ & 270 & 200 & 200 \\
Fish meal (FM) & 140 & 120 & 120 \\
Corn meal & 375 & 350 & 350 \\
Vitamin premix & 15 & 10 & 10 \\
Bone ash & 10 & 10 & 10 \\
Sodium chloride & 5 & 5 & 5 \\
(NaCl) & 5 & 5 & 5 \\
Vitamin C & 20 & 20 & 20 \\
Wheat flour & 10 & 10 & 10 \\
Palm oil & -- & 70 & 35 \\
G. kola & -- & -- & 35 \\
S. jamaicensis & & & \\
\hline & & & 5 \\
\hline
\end{tabular}

\section{Collection, authentication and preparation of plant materials}

G. kola seeds were obtained from Watt market in Calabar, Cross River State, Nigeria. The outer coats were removed and the seeds were sun- dried. The dried seeds were ground into fine powder and added to the feed. The leaves of $S$. jamaicensis were collected from the botanical garden of the University of Calabar and taken to Botany Department for identification and authentication. The leaves were washed to remove dirt and debris, thereafter, they were oven-dried at $75^{\circ} \mathrm{C}$ for 24 hours. After oven-drying, the dried leaves were ground into fine powder and added to the feed as treatment.

\section{Determination of growth performance}

Growth performance indices were calculated according to De Silva and Anderson (1995) and Eyo and Ekanem (2011) as shown below:

Mean wet weight gain: Final weight $\left(\mathrm{W}_{2}\right)$-Inital weight $\left(\mathrm{W}_{1}\right)$

Length increment: Final length $\left(L_{2}\right)$-Initial length $\left(L_{1}\right)$

Growth rate: (Final weight-Initial weight)/(Number of days)

Specific growth rate:

(In final weight)-(In initial weight)/(Number of days) $\times 100$

Mean growth rate:

[(final wt-Initial wt)/0.5(final wt+lnitial wt)(Number of days) ] $\times 1000$ 
\%survival:

[(Number of fish that survived)/(Number of fish stocked) $] \times 100$

Food Conversion Ratio: Total amount of feed given to the fish/ Total weight gained by the fish

\section{Measurement of water quality}

Water quality parameters measured included dissolved oxygen $(\mathrm{mg} / \mathrm{l}), \mathrm{pH}$, temperature $\left({ }^{\circ} \mathrm{C}\right)$, and ammonia $(\mathrm{mg} / \mathrm{l})$. Dissolved oxygen $(\mathrm{mg} / \mathrm{l})$ was measured using Portable Hanna dissolved oxygen meter Model HI9142, pH was measured with Portable waterproof $\mathrm{pH} / \mathrm{EC} / \mathrm{TDS}$ Hanna meter (high range) HI991301, temperature $\left({ }^{\circ} \mathrm{C}\right)$ was measured using mercury in glass thermometer and ammonia ( $\mathrm{mg} / \mathrm{l})$ using ammonia test kit.

Estimation of fecundity of experimental fish fed to the three experimental diets

Eggs from each female fish from the three treatments were removed after dissecting the fish with a sharp pair of scissors. Each specimen was cut-opened through the anus. Eggs were removed and washed in distilled water and weighed using Metlar-2000D electronic weighing balance to the nearest $0.1 \mathrm{~g}$ (Eyo et al. 2013). The eggs were fixed in Gilson fluid $(17 \mathrm{ml}$, Nitric acid, $4 \mathrm{ml}$ Glacial acetic acid, $20 \mathrm{~g}$ mercuric chloride, 95 $\%$ ethanol and $900 \mathrm{ml}$ distilled water) in order to harden the egg and loosen the tissues surrounding the eggs. Fecundity $(F)$ was determined following the method of Viveen et al. (1985) as the product of total weight of eggs in the ovary and count in $1 \mathrm{~g}$ of egg mass as follows:

Fecundity $(F)=$ total weight of eggs in the ovary $x$ count in $1 \mathrm{~g}$ of egg mass

\section{Measurement of egg size}

The diameters of 30 eggs per fish were measured according to Eyo et al. (2013) using a stereo microscope with a micrometer ocular eye piece.

Histology of the testis and ovary of fish fed the experimental diets

For histological analysis, ovary and testis of female and male $C$. gariepinus fed to the three experimental feeds were extracted and fixed in Bouin's fluid for 48 hours, manually processed and sectioned at $10 \mu$ with a rotary microtome,
Model SURGIPATH AS325, dewaxed in xylene, stained with haematoxylin, and eosin following Bancroft and Cook (1994) in preparation for microscopic examinations.

Calculation of Gonadosomatic index (GSI - \%) of Fish Fed the Experimental Diets

Gonadosomatic index (GSI) of female and male $C$. gariepinus fed the three experimental feeds was calculated according to Bolger and Connolly (1989) as follows:

GSI = [(Gonad weight $(\mathrm{g}) /$ Whole fish weight $(\mathrm{g})]$ X 100

\section{Statistical analysis}

Growth performance and food utilization data including mean weight gain $(\mathrm{g})$, length increment $(\mathrm{cm})$, growth rate $(G R)$, mean growth rate (MGR), specific growth rate (SGR), food conversion ratio (FCR) and \% survival were subjected to One Way Analysis of Variance (ANOVA) to determine if there were significant differences among fish fed to different experimental diets using Predictive Analytical Software (PASW) program for statistical analysis (version 18.0) developed by SPSS Hong Kong Headquarters. Effects with a probability of $(P<0.05)$ were considered significant.

\section{RESULTS}

Growth performance and food utilization of $c$. gariepinus fed to the experimental diets

Growth performance indices (Table 2) showed that mean weight gain was the highest in fish fed diet $C(74.35 \pm 4.55 \mathrm{~g})$, followed by fish fed diet $A(69.50 \pm 3.5 \mathrm{~g})$ and the least in fish fed to diet $B(52.75 \pm 11.85 \mathrm{~g})$. Mean length gain was also the highest in fish fed to diet $C(10.00 \pm 0.10 \mathrm{~cm})$, followed by fish fed to diet $A(9.01 \pm 1.44 \mathrm{~cm})$ and the least in fish fed to diet $B$ $(7.48 \pm 1.03 \mathrm{~cm})$. Mean specific growth rate $(S G R)$ was the highest in fish fed to diet $A(1.62 \pm 0.11)$, followed by fish fed to diet $B(1.47 \pm 0.35)$ and the least in fish fed to diet C (1.24 \pm $0.21)$. Mean growth rate (MGR) was the highest in fish fed to diet $C(1.24 \pm 0.08)$, followed by fish fed to diet $A(1.07 \pm 0.04)$ and the least in fish fed to diet $B(0.88 \pm 0.20)$. Food conversion ratio (FCR) was the highest in fish fed to diet $C(3.39 \pm 1.02)$, followed by fish fed to diet $A(2.25 \pm 0.31)$ and the least in fish fed to diet $B(2.46 \pm 0.73)$.

Table 2. Mean growth indices and feed utilization of $c$. gariepinus fed to the experimental diets

\begin{tabular}{llll}
\hline & Diet A (Control) & Diet B (S. jamaicensis) & Diet C (G. kola + S. jamaicensis) \\
\hline Initial Length $(\mathbf{c m})$ & $13.40 \pm 0.20$ & $13.25 \pm 0.30$ & $13.30 \pm 0.25$ \\
Final Length $(\mathbf{c m})$ & $22.5 \pm 1.20$ & $20.73 \pm 1.50$ & $23.30 \pm 1.00$ \\
Length gain $(\mathbf{c m})$ & $9.10 \pm 1.44^{\mathrm{a}}$ & $7.48 \pm 1.03^{\mathrm{a}}$ & $10.00 \pm 0.10^{\mathrm{a}}$ \\
Initial Weight $(\mathbf{g})$ & $16.50 \pm 1.62$ & $16.40 \pm 2.50$ & $16.30 \pm 2.00$ \\
Final Weight $\mathbf{( g )}$ & $86.00 \pm 1.85$ & $69.15 \pm 9.63$ & $90.65 \pm 2.52$ \\
Weight gain $(\mathbf{g})$ & $69.50 \pm 3.50^{\mathrm{a}}$ & $52.75 \pm 11.85^{\mathrm{a}}$ & $74.35 \pm 4.55^{\mathrm{a}}$ \\
SGR & $1.62 \pm 0.11^{\mathrm{a}}$ & $1.47 \pm 0.35^{\mathrm{a}}$ & $1.24 \pm 0.21^{\mathrm{a}}$ \\
GR & $1.07 \pm 0.04^{\mathrm{a}}$ & $0.88 \pm 0.20^{\mathrm{a}}$ & $1.24 \pm 0.08^{\mathrm{a}}$ \\
FCR & $2.25 \pm 0.31^{\mathrm{a}}$ & $2.46 \pm 0.73^{\mathrm{a}}$ & $3.39 \pm 1.02^{\mathrm{a}}$ \\
\hline${ }^{*} \mathrm{SGR}=$ Specific growth rate (\%/day), GR = Growth Rate (g/day), FCR = Food Conversion Ratio. Means with the same superscript are not significantly different \\
$(\mathrm{P}>0.05)$
\end{tabular}




\section{Gonad weight of C. gariepinus fed to the experimental diets}

For female C. gariepinus fed to diet A (Control), gonad weight ranged between $8 \mathrm{~g}$ for fish with total length of $25.7 \mathrm{~cm}$ and total weight of $109 \mathrm{~g}$ to $23 \mathrm{~g}$ for fish with total length of $30.5 \mathrm{~cm}$ and total weight of $183 \mathrm{~g}$ with a mean of $12.13 \pm 1.68 \mathrm{~g}$. For female C. gariepinus fed to diet B (70 g of S. jamaicensis), gonad weight ranged between $2 \mathrm{~g}$ for fish with total length of $24.7 \mathrm{~cm}$ and total weight of $100 \mathrm{~g}$ to $16 \mathrm{~g}$ for fish with total length of $29.8 \mathrm{~cm}$ and total weight of $147 \mathrm{~g}$ with a mean of $9.50 \pm 1.48 \mathrm{~g}$. For female C. gariepinus fed to diet $C$ ( $35 \mathrm{~g}$ of $S$. jamaicensis + $35 \mathrm{~g}$ of $\mathrm{G}$. Kola), gonad weight ranged between $6 \mathrm{~g}$ for fish with total length of $24.8 \mathrm{~cm}$ and total weight of $85 \mathrm{~g}$ to $13 \mathrm{~g}$ for fish with total length of $29.3 \mathrm{~cm}$ and total weight of $168 \mathrm{~g}$ with a mean of $10.44 \pm 0.92 \mathrm{~g}$.

For male C. gariepinus fed to $\operatorname{diet} A$ (Control), gonad weight ranged between $0.5 \mathrm{~g}$ for fish with total length of $28.0 \mathrm{~cm}$ and total weight of $147 \mathrm{~g}$ to $2 \mathrm{~g}$ for fish with total length of $28.5 \mathrm{~cm}$ and total weight of $114 \mathrm{~g}$ with a mean of $1.11 \pm 0.15 \mathrm{~g}$. For male $C$. gariepinus fed to diet B (70 $\mathrm{g}$ of $\mathrm{S}$. jamaicensis), gonad weight ranged between $0.5 \mathrm{~g}$ for fish with total length of $25.0 \mathrm{~cm}$ and total weight of $86 \mathrm{~g}$ to $1.0 \mathrm{~g}$ for fish with total length of $30.2 \mathrm{~cm}$ and total weight of $145 \mathrm{~g}$ with a mean of $0.75 \pm 0.06 \mathrm{~g}$. For male C. gariepinus fed to diet C (35 g of $S$. jamaicensis $+35 \mathrm{~g}$ of $\mathrm{G}$. Kola), gonad weight ranged between $0.5 \mathrm{~g}$ for fish with total length of $25.7 \mathrm{~cm}$ and total weight of $62 \mathrm{~g}$ to $2 \mathrm{~g}$ for fish with total length of $32.5 \mathrm{~cm}$ and total weight of $207 \mathrm{~g}$ with a mean of 0.98 $\pm 0.22 \mathrm{~g}$. Table 3 shows the gonad weight of $C$. gariepinus fed to the experimental diets.

Table 3. Mean gonad weight of C. gariepinus fed to the experimental diets

\begin{tabular}{llll}
\hline & $\begin{array}{l}\text { Diet A } \\
\text { (Control) }\end{array}$ & $\begin{array}{l}\text { Diet B (S. } \\
\text { jamaicensis) }\end{array}$ & $\begin{array}{l}\text { Diet C (G. kola } \\
+ \text { S. } \\
\text { jamaicensis) }\end{array}$ \\
\hline $\begin{array}{l}\text { Female Gonad } \\
\text { weight }(\mathrm{g})\end{array}$ & $12.13 \pm 1.68^{\mathrm{a}}$ & $9.50 \pm 1.48^{\mathrm{a}}$ & $10.44 \pm 0.92^{\mathrm{a}}$ \\
$\begin{array}{l}\text { Male Gonad } \\
\text { weight }(\mathrm{g})\end{array}$ & $1.11 \pm 0.15^{\mathrm{a}}$ & $0.75 \pm 0.06^{\mathrm{a}} \mathrm{O}$ & $0.98 \pm 0.22^{\mathrm{a}}$ \\
\hline${ }^{*}$ Mean with the same superscript are not significantly different $(\mathrm{P}>0.05)$
\end{tabular}

Gonado-Somatic Index (GSI) and fecundity of C. gariepinus fed to the experimental diets

The mean gonad-somatic index (GSI) and fecundity of $C$. gariepinus fed to the experimental diets are presented in Table 4. For female C. gariepinus fed to diet A (Control), gonadosomatic index (GSI) ranged between $7.34 \%$ for fish with total length of $25.7 \mathrm{~cm}$ and total weight of $109 \mathrm{~g}$ to $14.71 \%$ for fish with total length of $23.2 \mathrm{~cm}$ and total weight of $68 \mathrm{~g}$ with a mean of $12.70 \pm 0.81 \%$. Mean fecundity of female $C$. gariepinus fed to diet $\mathrm{A}$ (Control) ranged between 7,808 eggs for fish with total length of $25.7 \mathrm{~cm}$ and total weight of $109 \mathrm{~g}$ to 22,448 eggs for fish with total length of $30.5 \mathrm{~cm}$ and total weight of $183 \mathrm{~g}$ with a mean of $11,834.00 \pm 1644$ eggs.
Table 4. Mean gonadosomatic index (gsi) and fecundity of $C$. gariepinus fed to the experimental diets

\begin{tabular}{llll}
\hline & $\begin{array}{l}\text { Diet A } \\
\text { (Control) }\end{array}$ & $\begin{array}{l}\text { Diet B (S. } \\
\text { jamaicensis) }\end{array}$ & $\begin{array}{l}\text { Diet C (G. kola + } \\
\text { S. jamaicensis) }\end{array}$ \\
\hline $\begin{array}{l}\text { Female } \\
\text { GSI (\%) }\end{array}$ & $12.70 \pm 0.81^{\mathrm{a}}$ & $10.54 \pm 1.72^{\mathrm{a}}$ & $8.85 \pm 0.99^{\mathrm{a}}$ \\
$\begin{array}{l}\text { Male GSI } \\
(\%)\end{array}$ & $1.39 \pm 0.01^{\mathrm{a}}$ & $0.94 \pm 0.15^{\mathrm{b}}$ & $0.95 \pm 0.05^{\mathrm{c}}$ \\
Fecundity & $\begin{array}{l}11,834.00 \pm \\
1644^{\mathrm{a}}\end{array}$ & $6374.5 \pm 991^{\mathrm{b}}$ & $10,2356 \pm 896^{\mathrm{c}}$ \\
& & & \\
\hline
\end{tabular}

*Means with the same superscript are not significantly different $(P>0.05)$

For female C. gariepinus fed to diet B $(70 \mathrm{~g}$ of $\mathrm{S}$. jamaicensis), gonadosomatic index (GSI) ranged between $2.0 \%$ for fish with total length of $24.7 \mathrm{~cm}$ and total weight of $100 \mathrm{~g}$ to $22.22 \%$ for fish with total length of $22.3 \mathrm{~cm}$ and total weight of $63 \mathrm{~g}$ with a mean of $10.54 \pm 1.72 \%$. Fecundity of female $C$. gariepinus fed to diet $B$ ( $70 \mathrm{~g}$ of $S$. jamaicensis) ranged between 2,013 eggs for fish with total length of $21.8 \mathrm{~cm}$ and total weight of $64 \mathrm{~g}$ to 10,065 eggs for fish with total length of $26.7 \mathrm{~cm}$ and total weight of $123 \mathrm{~g}$ with a mean of $6375 \pm 991.48$ eggs.

For female C. gariepinus fed to diet $C(35 \mathrm{~g}$ of $S$. jamaicensis and $35 \mathrm{~g}$ of $\mathrm{G}$. kola), gonadosomatic index (GSI) ranged between $5.29 \%$ for fish with total length of $30.3 \mathrm{~cm}$ and total weight of $189 \mathrm{~g}$ to $14.29 \%$ for fish with total length of 23.5 $\mathrm{cm}$ and total weight of $84 \mathrm{~g}$ with a mean of $8.85 \pm 0.99 \%$. Fecundity of female $C$. gariepinus fed to diet $C$ ( $35 \mathrm{~g}$ of $S$. jamaicensis and $35 \mathrm{~g}$ of $\mathrm{G}$. kola) ranged between 5,880 eggs for fish with total length of $24.8 \mathrm{~cm}$ and total weight of $85 \mathrm{~g}$ to 12,740 eggs for fish with total length of $24.7 \mathrm{~cm}$ and total weight of $101 \mathrm{~g}$ with a mean of $10,235.56 \pm 896.27$ eggs.

For male C. gariepinus fed to diet A (Control), gonadosomatic index (GSI) ranged between $0.34 \%$ for fish with total length of $28.0 \mathrm{~cm}$, total weight of $147 \mathrm{~g}$ and testis weight of $0.5 \mathrm{~g}$ to $1.89 \%$ for fish with total length of $21.2 \mathrm{~cm}$, total weight of $53 \mathrm{~g}$ and testis weight of $1 \mathrm{~g}$ with a mean of $1.39 \pm 0.01 \%$. For male C. gariepinus fed to diet B (70 g of $\mathrm{S}$. jamaicensis), gonadosomatic index (GSI) ranged between $0.34 \%$ for fish with total length of $30.4 \mathrm{~cm}$, total weight of $175 \mathrm{~g}$ and testis weight of $0.6 \mathrm{~g}$ to $1.79 \%$ for fish with total length of $21.3 \mathrm{~cm}$, total weight of $56 \mathrm{~g}$ and testis weight of $1 \mathrm{~g}$ with a mean of $0.94 \pm 0.15 \%$. For male $C$. gariepinus fed to diet $\mathrm{C}$ ( $35 \mathrm{~g}$ of $S$. jamaicensis and $35 \mathrm{~g}$ of $\mathrm{G}$. kola), gonadosomatic index (GSI) ranged between $0.81 \%$ for fish with total length of $25.7 \mathrm{~cm}$, total weight of $62 \mathrm{~g}$ and testis weight of $0.5 \mathrm{~g}$ to $1.16 \%$ for fish with total length of $24.4 \mathrm{~cm}$, total weight of $86 \mathrm{~g}$ and testis weight of $1 \mathrm{~g}$ with a mean of $0.95 \pm 0.05 \%$. Figure 1 shows the gonad of male and female C. gariepinus fed to the three experimental diets.

Histology of $C$. gariepinus gonads fed to the three experimental diets

The histology of ovaries (Figure 2) and testes (Figure 3) of fish fed to the three experimental diets showed normal distribution of cells in their development. For females fed to the three experimental diets, the oocytes were fully developed. 
Also, testis of males fed to the three experimental diets, showed normal distribution of the testicular cells.

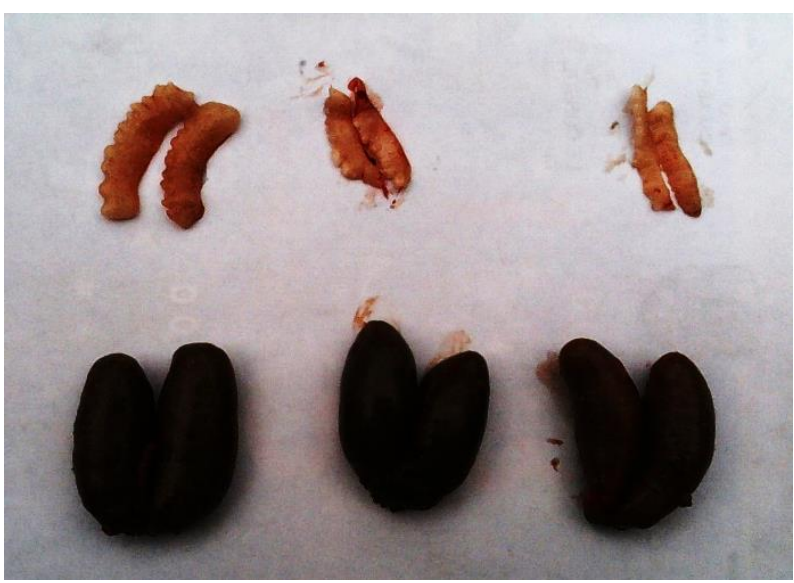

Figure 1. Gonad of Male (up) and female (below) C. gariepinus fed to the three experimental diets. (a) Ovary and Testis of fish fed to Feed A (Control) (b) Ovary and Testis of fish fed to Feed B (70 g of $S$ jamaicensis) (c) Ovary and Testis of fish fed Feed C ( $35 \mathrm{~g}$ of G. kola + $35 \mathrm{~g}$ of $\mathrm{S}$. jamaicensis)

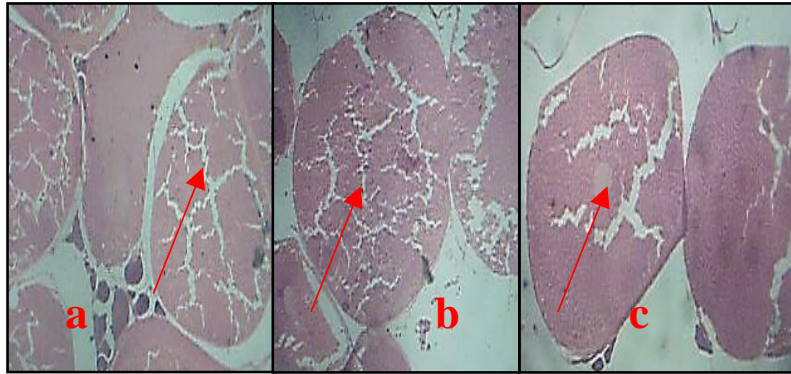

Figure 2: (a) Histological section of ovaries (Mag. x 100) of fish fed to Feed A (Control) (b) ovaries of fish fed to Feed B (70 g of $S$. jamaicensis) and (c) ovaries of fish fed Feed C ( $35 \mathrm{~g}$ of G. kola $+35 \mathrm{~g}$ of $S$. jamaicensis). Arrow indicates matured oocytes

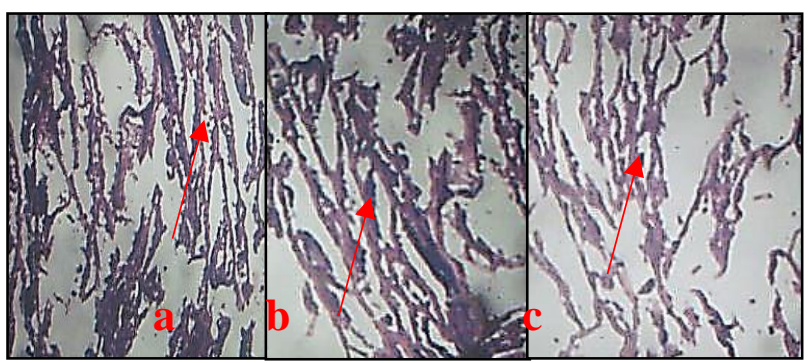

Figure 3. (a) Histological section of testis (Mag. $x$ 100) of fish fed to Feed A (Control) (b) testis of fish fed to Feed B (70 g of S. jamaicensis) and (c) testis of fish fed Feed C (35 g of G. kola $+35 \mathrm{~g}$ of $\mathrm{S}$. jamaicensis). Arrow indicates matured sperm cells tanks

Mean physicochemical parameters of experimental

Water quality analysis of treatment tanks (Table 5 ) showed that in treatment $\mathrm{A}$ (fed to control diet), mean $\mathrm{pH}$ was 6.96 \pm 0.25 , mean dissolved oxygen was $4.88 \pm 0.20 \mathrm{mg} / \mathrm{land}$ mean temperature was $30.2 \pm 0.10^{\circ} \mathrm{C}$. In treatment $\mathrm{B}$ (fed to diet $\mathrm{B}$ containing $70 \mathrm{~g}$ of $\mathrm{S}$. jamaicensis), mean $\mathrm{pH}$ was $6.88 \pm 0.12$, mean dissolved oxygen was $4.60 \pm 0.22 \mathrm{mg} / \mathrm{land}$ mean temperature was $30.0 \pm 0.20^{\circ} \mathrm{C}$. In treatment $\mathrm{C}$ (fed to diet $\mathrm{B}$ containing $35 \mathrm{~g}$ of $S$. jamaicensis and $35 \mathrm{~g}$ of $\mathrm{G}$. kola), mean $\mathrm{pH}$ was $7.10 \pm 0.24$, mean dissolved oxygen was $4.82 \pm 0.10$ $\mathrm{mg} /$ land mean temperature was $30.5 \pm 0.10^{\circ} \mathrm{C}$.

Table 5. Mean physicochemical parameters of experimental tanks

\begin{tabular}{llll}
\hline Parameters & Tank A & Tank B & Tank C \\
\hline $\mathrm{pH}$ & $6.96 \pm 0.25$ & $6.88 \pm 0.12$ & $7.10 \pm 0.24$ \\
$\mathrm{DO}(\mathrm{mg} / \mathrm{L})$ & $4.88 \pm 0.20$ & $4.60 \pm 0.22$ & $4.82 \pm 0.10$ \\
Temperature $\left({ }^{\circ} \mathrm{C}\right)$ & $30.2 \pm 0.10$ & $30.0 \pm 0.20$ & $30.5 \pm 0.10$ \\
\hline
\end{tabular}

\section{DISCUSSION}

The results obtained in this study show that $C$. gariepinus fed to the three experimental diets responded positively as observed in the growth performance and survival of the test fish. Result of growth indices such as mean length gain, weight gain, mean specific growth rate (SGR), and mean growth rate (GR) of $C$. gariepinus fed to the three experimental diets were not significantly different $(P>0.05)$ although the highest values were obtained in fish fed to diet $C$ containing $35 \mathrm{G}$. kola and $S$. jamaicensis, followed by fish fed to $\operatorname{diet} A$ (Control) and the least in fish fed to diet $\mathrm{C}$. These findings are similar to those of Dada and lkuerowo (2009) who reported improved growth of $C$. gariepinus broodstock when fed to dietary inclusion of ethanolic extracts of G. kola. Also, Adedeji et al. (2006) reported similar results in pullet chicks when fed to on different inclusion levels of G. kola dry seeds powder. According to De Silva and Anderson (1995), a high quality feed is expected to meet the nutrient requirement of an animal. This fact indicates that the three experimental feeds were good in quality since the experimental fishes showed positive growth performance. Eyo and Ekanem (2011) reported that nutrients must be able to be digested and absorbed in a form that makes them available for providing energy and substrate for growth (bioavailability). The result of growth obtained in this study indicates that nutrients from the three experimental diets were digested and absorbed efficiently by the experimental fishes. The least growth indices obtained in fish fed to diet B containing $70 \mathrm{~g}$ of $\mathrm{S}$. jamaicensis could be attributed to the presence of anti-nutrients in the Brazilian tea leaf meal. According to Francis et al. (2001), Ekanem et al. (2010) and Fagbenro (1999), reduction in antinutrient could be achieved by different processing techniques and will result in better palatability and growth in fish. In this study, the Brazilian tea leaf meal ( $S$. jamaicensis) was processed according to standard methods, but it is possible that anti-nutrients are not reduced to $0 \%$ level. Since feed is expensive, feed conversion ratio (FCR) or feed conversion efficiency (FCE) are important calculations for the fish to determine if feed is being used as efficiently as possible (Eyo 
and Ekanem, 2011). Also, Ekanem et al. (2010) reported that the growth and feed conversion ratio of a fish are important tools in computing the acceptability of artificial feed. The feed conversion ratio (FCR) of different fish species have been determined by many workers including, Jhingran, (1991), Ekanem et al. (2010), Shabbir et al. (2003), and many others. In this study, food conversion ratio (FCR) was the highest in fish fed to diet $C$ ( $3.39 \pm 1.02)$, followed by fish fed to diet $B(2.46 \pm$ $0.73)$ and the least in fish fed to diet $A(2.25 \pm 0.31)$ implying that fish fed to control diet had the best FCR. This finding could be attributed to the presence of plant materials in diets $B$ and C. According to Ekanem et al. (2010) high fiber content is a major problem when leaf meals are used in fish diets as this can impair fish growth through poor food utilization. The results obtained in this present study support the findings of Eyo et al. (2014) and Eyo et al. (2012) that utilization of good quality feeds plays a major role in gonad development in C. gariepinus. Generally, mean gonad weight of female $C$. gariepinus was the highest $(12.13 \pm 1.68 \mathrm{~g})$ in female fish fed to diet $\mathrm{A}$ (Control) followed by fish fed to diet $C(10.44 \pm 1.48 \mathrm{~g})$ and the least in fish fed to diet $B(9.50 \pm 1.48 \mathrm{~g})$. In males, gonad weight also followed the same trend with the highest gonad weight (1.11 \pm $0.15 \mathrm{~g}$ ) obtained for $C$. gariepinus fed to $\operatorname{diet} A$ (Control), followed by fish fed to diet $C(0.98 \pm 0.22 \mathrm{~g})$ and the least in fish fed to diet $B(0.75 \pm 0.06 \mathrm{~g})$. These results has showed that gonad growth in both male and female $C$. gariepinus cannot be significantly influenced $(P>0.05)$ by inclusion of $G$. kola and $S$. jamaicensis leaf meal in their diets. However, variations seen in the gonad weight of both male and female C. gariepinus could be attributed to the presence of plant materials in diets $B$ and $C$, and also the presence of high fiber content in plant materials which is a major problem when leaf meals are used in fish diets as reported by Ekanem et al. (2010) and Ekanem et al. (2012). Mean gonadosomatic index (GSI) of female $C$. gariepinus was the highest $(12.70 \pm 0.81 \%)$ in female fish fed to diet $\mathrm{A}$ (Control) followed by fish fed to diet $\mathrm{C}(10.54 \pm 1.72$ $\%)$ and the least in fish fed to diet B $(8.85 \pm 0.99 \%)$. In males, gonad weight also followed the same trend with the highest gonad weight $(1.11 \pm 0.15 \mathrm{~g})$ obtained for $C$. gariepinus fed to

\section{REFERENCES}

Adedeji, O. S., Farinu, G.O., Oluyeni, T.B., Ameen, S.A. \& Babatunde, G.M. (2008). The use of bitter kola (Garcinia kola) dry seed powder as a natural growth promoting agent in broiler chicks. Research Journal of Poultry Science, 2: 78-81.

Adeparusi, E. O., Dada. A. A., \& Alale, O. V. (2010). Effects of Medicinal Plant (Kigelia Africana) on Sperm Quality of African Catfish Clarias gariepinus (Burchell, 1822) Broodstock. Journal of Agriculture, 2(1): 193-199.

Ajayi, A. I., Olaifa, F. E., \& Omoniy, M. M. (2013). Chemical Analysis and Nutritional Assessment of Defatted Garcinia mangostana Seeds Used as an Additive on the Feed of Fish (Clarias gariepinus). Global Journal of Science Frontier Research Chemistry, 13 (2):1-12.

Awom, I. E., \& Eyo, V. O. (2016). Comparative Study of Growth Performance Food Utilization and Survival of the African Catfish Clarias gariepinus (Burchell, 1822) Fingerlings Fed Live Maggot (Musca domestica) and Coppens Commercial Feed. International Journal of Scientific Research in Science, Engineering and Technology, 2(2): 379-386. $\operatorname{diet} A$ (Control), followed by fish fed to $\operatorname{diet} C(0.98 \pm 0.22 \mathrm{~g})$ and the least in fish fed to diet $\mathrm{B}(0.75 \pm 0.06 \mathrm{~g})$. The $\mathrm{GSI}$ result for female $C$. gariepinus obtained in this study is within the range reported by Eyo et al. (2014), but GSI for male C. gariepinus fed to the three experimental feed, obtained in this study is lower than the range reported by Eyo et al. (2014). This difference could be attributed to the size variation of the male fish used in this study. Fecundity was high in all treatments, although fish fed to control diet exhibited the highest fecundity $(11,834 \pm 1643.93)$. Fecundity of fish fed to the control diet was significantly higher than fecundity of fish fed to diet $B$ and diet C. Adeparusi et al. (2010) also reported similar findings on the use of medicinal plants for catfish C. gariepinus. Histology of ovaries and testes of fish fed to the three experimental diets in this study showed normal distribution of oocytes and testicular cells.

In the present study, physicochemical parameters including water temperature, $\mathrm{pH}$, and dissolved oxygen were within the acceptable range for fish growth and health as recommended by Boyd (1979) and Goos and Richter (1996). This indicates that the growth, survival, fecundity, and gonad development of the experimental fishes were not affected by physicochemical parameters of the culture tanks.

\section{CONCLUSION}

This study, therefore, infers that plant materials such as Brazilian tea ( $S$. jamaicensis) and bitter kola (G. kola) seed powder can be included in the diet of $C$. gariepinus in order to reduce cost of fish culture and dependence on synthetic chemicals as growth and reproduction booster. However, growth and reproduction may be negatively affected if plant materials are not processed according to recommended methods to reduce anti-nutrients. Also, reduced palatability as a result of high fibre content may lead to a reduced feed consumption which will negatively influence growth performance in fish. This problem may be overcomed by using ethanolic extract.

Bancroft, J. D., \& Cook, H. C. (1994). Manual of histopathological techniques and their diagnostic application. Churchill Livingstone, London, pp. 305.

Becker, B. N. (2004)., M.Sc. Thesis, 32p

Bolger, J., \& Connolly, P. L. (1989). The selection of suitable indices for the measurement and analysis of fish condition. Journal of Fish Biology, 34: 171- 182. doi: 10.1111/j.1095-8649.1989.tb03300.x

Boyd, C. E. (1979. Water Quality in Warmwater Fish Ponds. Auburn University Agriculture Experiment Station, Auburn, Alabama.

Dada, A. A., \& Ebhodaghe, B. E. (2011). Effect of Garcinia kola seed Meal on Egg Quality of the African Catfish (Clarias gariepinus) (Burchell) Broodstock. Cameroon Journal of Experimental Biology 2011 Vol. 07 $N^{\circ} 01,1-8$

Dada, A. A., \&Ogunduyile, F. D. (2011). Effects of Velvet Bean (Mucunapruriens) on Sperm Quality of African Catfish, Clariasgariepinus(Burchell, 1822) Broodstock. Journal of Fisheries and Aquatic Science, 1: 1-7. 
Dada, A.A., \& lkuerowo, M. (2009). Effects of ethanolic extracts of Garcinia kola seeds on growth and haematology of catfish (Clarias gariepinus) broodstock. African Journal of Agriculture Research, 4: 344-347

De Silva, S. S., \& Anderson, T. A. (1995). Fish Nutrition in Aquaculture. London, Ghapman and Hall, 319pp.

Ekanem, A. P., Eyo, V. O., \& Ndome, C. B. (2010). The effect of diet with different inclusion level of cassava leaf meal (CLM) Manihot utilissima on the growth performance of Heteroclarias fingerlings. Journal of Science and Multidisciplinary Research, 2:58-67.

Ekanem, A. P., Eteng, S. U., Nwosu, F. M., \& Eyo, V. O. (2012). Comparative Study of the Growth and Gonad Development of Clarias gariepinus (Burchell 1822) Fed Diets with Plant and Animal-based Ingredients in Concrete Tanks. Journal of Agricultural Science and Technology, 2:12031210 .

Eyo, V. O., \& Ekanem, A. P. (2011). Effect of feeding frequency on the growth food utilization and survival of African catfish (Clarias gariepinus) using locally formulated diet. African Journal of Environmental Pollution and Health 9 (2): 11-17.

Eyo, V. O., Ekanem, A. P., \& Obiekezie, A. I. (2012). A comparative study of egg and sperm quality of Clarias gariepinus fed Unical aqua feed and Coppens commercial feed. International Journal of Biology, Pharmacy and Allied Science,1(11): 1598-1607.

Eyo, V. O., Ekanem, A. P., \& Ufon-ima, U. J. (2014). A comparative study of the gonado-somatic index (GSI) and gonad gross morphology of African Catfish (Clarias gariepinus) fed Unical Aqua feed and Coppens Commercial feed. Croatian Journal of Fisheries,72: 63 - 69. doi $10.14798 / 72.2 .706$
Eyo, V. O., Ekanem, A. P., Eni, G. E., \& Asikpo, P. E. (2013). Relationship between fecundity and biometric indices of the Silver Catfish Chrysichthys nigrodigitatus(Lacepede) in the Cross River estuary, Nigeria. Croatian Journal of Fisheries, 71:131-135. doi: 10.14798/71.3.662

Fagbenro, O. A. (1999). Comparative evaluation of heatprocessed winged bean (Psophocarpus tetragonolobus) meals as partial replacement for fishmeal in diets for African catfish (Clarias gariepinus). Aquaculture, 170: 297-305. doi: 10.1016/S0044-8486(98)00409-8

Francis G., Makkar, H. P. S., \& Becker, K. (2001). Antinutritional factors present in plant-derived alternate fish feed ingredients and their effects in fish. Aquaculture, 199: 197-227. doi: 10.1016/S0044-8486(01)00526-9

Goos H. J. T., \& Richter, C. J. J. (1996) Internal and external factors controlling reproduction in the African catfish, Clarias gariepinus. Aquatic Living Resources, 9: 45-58. doi: 10.1051/alr:1996041

Iwu M.W. (1993). Handbook of African Medicinal Plant. CRC Press. Boca Raton. Ann Arbor London. Tolryo:183 -184.

Jhingran, V. G. (1991). Fish and Fisheries of India. 3rd Ed., Hindustan Publishing Co., Delhi, India.

Shabbir, S., Salim, M., \& Rashid, M. (2003) Study on the feed conversion ratio (FCR) in major carp Cirrhinus mrigala fed on sunflower meal, wheat bran and maize gluten. Pakistan Veterinary Journal, 23: 1-3.

Viveen, W. J., Ritcher, C. J. J., Van-Oordt, P. G.W., Janssen, J. A. L. \& Huisman, E.A. (1985). Manual for the culture of the African catfish (Clarias gariepinus). The Netherlands: Directorate General for International Tech. Cooperation. The Hague, p. 93.

Wikkipedia (2016). Stachytarphetajamaicensis. Retrieved 30th April, 2016 